\title{
Prevalence and Determinants of Low Birth Weight in Ethiopia: A Systematic Review and Meta-Analysis
}

\author{
Nuradin Abusha Katiso $\mathbb{D}^{1},{ }^{1}$ Getachew Mullu Kassa ${ }^{(D)},{ }^{2}$ Gedefaw Abeje Fekadu $\mathbb{D}^{3}$, \\ Abadi Kidanemariam Berhe $\mathbb{D}^{4},{ }^{4}$ and Achenef Asmamaw Muche ${ }^{5}$ \\ ${ }^{1}$ Department of Public Health, College of Medicine and Health Sciences, Wahemo University, Hossanna, Ethiopia \\ ${ }^{2}$ College of Health Sciences, Debre Markos University, Debre Markos, Ethiopia \\ ${ }^{3}$ School of Public Health, College of Medicine and Health Sciences, Bahir Dar University, P.O.Box 79, Bahir Dar, Ethiopia \\ ${ }^{4}$ Adigrat University, College of Medicine and Health Science, Tigray, Ethiopia \\ ${ }^{5}$ Department of Epidemiology and Biostatistics, Institute of Public Health, University of Gondar, Gondar, Ethiopia
}

Correspondence should be addressed to Nuradin Abusha Katiso; nuradinabusha@yahoo.com

Received 27 November 2019; Revised 29 April 2020; Accepted 16 May 2020; Published 15 September 2020

Academic Editor: Jagdish Khubchandani

Copyright ( 2020 Nuradin Abusha Katiso et al. This is an open access article distributed under the Creative Commons Attribution License, which permits unrestricted use, distribution, and reproduction in any medium, provided the original work is properly cited.

\begin{abstract}
Introduction. Low birth weight (LBW) is the most significant risk factor for neonatal and infant mortality. It is one of the major public health problems in developing countries. Although there are various studies on low birth weight, findings were inconsistent and inconclusive. Therefore, this study was conducted to estimate the national-pooled prevalence of low birth weight and its associated factors in Ethiopia. Method. Preferred Reporting Items for Systematic Reviews and Meta-Analyses (PRISMA) guideline was followed. This meta-analysis employed a review of both published and unpublished studies conducted in Ethiopia. The databases used were PubMed, Google Scholar, CINAHL, and African Journals Online. Relevant search terms for prevalence and determinants of LBW were used to retrieve articles. The meta-analysis was conducted using STATA 14 software. Forest plots were used to present the findings. The Cochran $Q$ test and $I^{2}$ test statistics were used to test heterogeneity across studies. Egger's test was used to assess the publication bias of included studies. The pooled prevalence and the odds ratios (OR) with $95 \%$ confidence intervals (CI) were computed and were presented using forest plots. Results. A total of 28 studies, 50,110 newborn babies, were included in this meta-analysis. The pooled prevalence of LBW in Ethiopia was $14.1 \%(95 \% \mathrm{CI}=11.2,17.1)$. Higher variation in the prevalence of LBW in different regions across the country was observed. Significant association of LBW with sex of the newborn baby, higher odds among female babies $(\mathrm{OR}=1.5(95 \% \mathrm{CI}=1.2,1.7))$, prematurity $(\mathrm{OR}=4.7(95 \% \mathrm{CI}=1.5,14.5))$, not attending prenatal care $(\mathrm{OR}=1.7(95 \% \mathrm{CI}=1.4,2.2))$, pregnancy-induced hypertension $(\mathrm{OR}=6.7(95 \% \mathrm{CI}=3.5,12.9))$, and newborn babies whose mothers were from rural areas $(\mathrm{OR}=1.8(95 \% \mathrm{CI}=1.2,2.6)$ were the factors associated with low birth weight. Conclusions. The prevalence of LBW in Ethiopia was high. LBW was associated with several maternal and newborn characteristics. The large disparity of LBW among the different regions in the country needs targeted intervention in areas with higher prevalence. Particular emphasis should be given to mothers residing in rural areas. Community-based programs are important to increase the use of prenatal care.
\end{abstract}

\section{Introduction}

World Health Organization (WHO) defined low birth weight (LBW) as infants whose weight is less than 2500 gram at birth irrespective of gestational age [1]. It is one of the major public health problems globally, with a higher prevalence in developing countries [1-4]. Reports showed that $16 \%$ of all births globally were low birth weight, representing more than 20 million births a year $[5,6]$. Furthermore, LBW is a significant predictor of prenatal mortality and morbidity, especially in sub-Saharan African countries. It is also associated with a range of short- and long-term consequences including chronic disease in later life $[1-5,7]$. 
Several studies identified prematurity and intrauterine growth restriction as predominant causes of low birth weight. Prematurity is the leading reason in developed countries, whereas intrauterine growth restriction is in developing ones $[1,6,8]$. Additionally, inadequate weight gain during pregnancy, low prepregnancy weight, short stature, sex of the newborn (being female), hard physical work during pregnancy, illness(especially infections), the lower status of women, and lack of antenatal care (ANC) are also identified as risk factors for low birth weight in developing countries [9-12]. Multiple gestations, young maternal age, primiparity, low education level, poor maternal nutrition before and during pregnancy, and lower maternal anthropometric measurements are also associated with low birth weight [13-20].

Various studies were conducted to estimate the prevalence and determinants of low birth weight in Ethiopia. The prevalence of low birth weight in various studies conducted in Ethiopia ranged from $6 \%$ to $29.1 \%$ [21-47]. Additionally, sex of the infant, pregnancy-induced hypertension, ANC follow-up, prematurity, parity, and residence were found to be associated with low birth weight [21-50].

However, most of these studies found inconclusive findings, especially on the factors associated with LBW. Moreover, most of the available studies in Ethiopia were conducted using small sample size limited to a certain region or area. Therefore, this study was conducted to pool the available studies in the country and to present the national estimate of LBW and selected factors associated with it. The findings of this study will be important to design better health policies to prevent LBW and to design policies which can target the identified factors. Additionally, it will assist the country to provide information that can suggest areas of intervention and help achieve the national and international maternal and child health-related goals and targets.

\section{Methods}

2.1. Study Design and Search Strategy/Data Sources. A systemic review and meta-analysis on the prevalence and determinant factors of low birth weight in Ethiopia were performed using the published and unpublished research articles. Major databases such as PubMed, Google Scholar, CINAHL, and African Journals Online (AJOL) were used to review published studies. In addition, we have used Google to retrieve unpublished studies from the official website of Addis Ababa University electronic database [51]. All published articles up to July 30, 2017 were included in this review. The reference list of already identified studies was also searched to retrieve additional articles. The online search was carried out using the following search terms and phrase: "prevalence of low birth weight, low birth weight, abnormal birth weight, newborn, neonate, underweight, infant, factors affecting low birth weight; pregnancy-induced hypertension (PIH) and low birth weight, parity and low birth weight, ANC and LBW, preterm delivery and LBW, and residence and LBW, Ethiopia" separately, and/or in combination using the Boolean operators to fit PubMed database, the following search strategy was applied: birth weight [MeSH Term] OR low birth weight OR abnormal birth weight OR normal birth weight OR underweight OR big baby weight OR macrosomia AND newborn [MeSH Term] OR neonate OR infant AND Ethiopia.

2.2. Study Selection and Eligibility Criteria. The following criteria were used to include and exclude studies from the review.

\subsubsection{Inclusion Criteria}

(i) Participants: this review included all studies, irrespective of characteristics of participants, that were conducted on prevalence and factors associated with low birth weight in Ethiopia

(ii) Setting: all studies conducted in community or institution level

(iii) Definition: all research studies that define LBW as birth weight less than 2,500 grams

(iv) Publication types: journal articles, master's thesis, and dissertations

(v) Studies published only in the English language were included in the review

(vi) Timeframe: all studies irrespective of the time of data collection or publication were included

\subsubsection{Exclusion Criteria}

(i) Research studies that did not report outcome variable of this review were excluded

(ii) Qualitative studies were excluded from the analysis

(iii) Studies with methodological problems and review articles were also excluded from the review

2.3. Data Extraction. The data extraction was performed by five researchers using a data extraction tool. The researcher developed the data extraction tool. The tool included information on the name of the author, publication year, study design, data collection period, sample size, study area, the age of study participants, response rate, the definition used for low birth weight, the prevalence of low birth weight, and maternal and newborn-associated factors.

2.4. Quality Assessment and Data Collection. Retrieved articles were assessed for inclusion using their title and abstract, and then, a full review of articles for quality assessment was performed before selecting for final review. Researchers used the Joanna Briggs Institute Meta-Analysis of Statistics Assessment and Review Instrument (JBIMAStARI) for critical appraisal. Two reviewers independently assessed the articles for inclusion in the review using the instrument. The disagreement (on article selection and data extraction), which arose between the reviewers, was resolved through discussion and by involving a third reviewer. The quality of all studies included in this review after the final full article review was also assessed. 
2.5. Publication Bias and Heterogeneity. Publication bias and heterogeneity were also assessed. Egger's test was used to check the publication bias of studies. Statistically significant publication bias was declared at a $p$ value less than 0.05 . The heterogeneity of studies was tested using $I^{2}$ test statistics. $I^{2}$ test statistics result of $25 \%, 50 \%$, and $75 \%$ was declared as low, moderate, and high heterogeneity, respectively. The random effect model was used for meta-analysis test results, which indicates statistically significant heterogeneity. Also, trim and fill analysis was conducted for studies with statistically significant publication bias using the random effect methods of analysis.

2.6. Statistical Methods and Analysis. The analysis was conducted using STATA version 14 software. The forest plot was used to present the combined estimate and odds ratio (OR) with the 95\% confidence interval. For studies, which did not present standard error (SE), it was calculated using the formula $\mathrm{SE}=\sqrt{p x[1-p]} / n$. The calculated standard error and prevalence rate of each study was then entered into STATA software to calculate the overall prevalence and its 95\% CI. The pooled OR was used to show the effect of sex of neonates, pregnancy-induced hypertension, antenatal care booking, gestational age, parity, residence, and pregnancy intention on low birth weight.

\section{Results}

3.1. Study Selection. This systematic review and metaanalysis included all published and unpublished studies on LBW conducted in Ethiopia. Search for articles using databases resulted in a total of 1,004 articles. After screening all articles using their title, abstract, and full paper review, a total of 28 articles were selected for the final meta-analysis (Figure 1).

3.2. Characteristics of Included Studies. The mean birth weight of babies included in the review ranged from 2,077 to 3,147 grams, and the sample size ranges from 253 to 11,872 . Overall, this review included a total of 50,110 newborn babies (Table 1). The majority [17] of the included studies were cross-sectional, 8 were cohort, and 3 were case-control studies. Most of the regions in Ethiopia (Oromia, Amhara, Tigray, SNNPR regions, Addis Ababa city, and Dire Dawa city) were represented in this review. Two of the studies were nation-based studies. The publication year of the studies was from 1990 to 2017 (Table 2).

The quality of included studies was assessed using a quality assessment toot based on the JBI critical appraisal tool checklists for cross-sectional (19 studies), case-control (3 studies), and cohort (7 studies). Accordingly, the quality score of studies that used a cross-sectional study design ranged from $75 \%$ to $93.75 \%$. For research studies that used cohort study design, the quality score ranged from $64 \%$ to $77 \%$, and for case-control studies, the quality score ranged from $72 \%$ to $89 \%$ (Additional files 1-3).
3.3. Prevalence of Low Birth Weight. The prevalence of LBW ranged from $6 \%$ to $29.1 \%$. The highest prevalence of LBW was observed in Tigray region $(15.4 \%(95 \% \mathrm{CI}=08.6,22.2))$ and the lowest was in Addis Ababa city (8.7\% (95\% CI = 8.0, 9.3)). The final pooled prevalence of LBW in Ethiopia was $14.1 \%(95 \% \mathrm{CI}=11.2,17.1)$. The $I^{2}$ test result showed the presence of high heterogeneity $\left(I^{2}=98.9 \%, p\right.$ value $=<0.001$ ). To address this heterogeneity, the random effect method of analysis was used for the meta-analysis (Figure 2).

3.4. Sex Difference in $L B W$. Seven of the studies included in this review showed that the sex of the newborn is associated with low birth weight $[24,25,30,39,45-47]$. In four studies, there was no significant difference in birth weight and sex of the newborn [26, 34, 43, 48]. However, the final pooled estimate showed that female newborn babies are at a higher risk of low birth weight than males, OR $=1.46(95 \%$ $\mathrm{CI}=1.22$, 1.73) (Figure 3).

3.5. Prenatal Care and $L B W$. A total of 14 studies were included in this category of meta-analysis [22, 24-26, 30, 34, 40, 43, 45-50]. Eight of these studies showed a significant association between the absence of antenatal follow-up with a higher risk of LBW [24, 34, 40, 43, 45, 47-49]. Altogether, this meta-analysis showed that babies born from women who had no prenatal care were 1.7 times more likely to have low birth weight babies, $\mathrm{OR}=1.72(95 \% \mathrm{CI}=1.35,2.2)$ (Figure 4$)$.

3.6. Preterm Delivery and $L B W$. Six of the studies included in this meta-analysis showed that preterm babies (delivered before 37 weeks of gestation) were more likely to be low birth weight $[29,34,40,45,46,50]$. While one study showed the opposite finding [22], and one study showed no difference in prevalence of LBW between preterm and term babies [26]. This meta-analysis showed a significant association between preterm delivery and low birth weight, $\mathrm{OR}=4.7 \quad(95 \% \quad \mathrm{CI}=1.53,14.42)$ (Figure 5).

3.7. Pregnancy-Induced Hypertension and $L B W$. Five studies were included in this category of meta-analysis $[22,39,43,46,50]$. The pooled meta-analysis showed the presence of an association between pregnancy-induced hypertension and low birth weight, $\mathrm{OR}=6.7(95 \% \mathrm{CI}=3.48$, 12.92) (Figure 6).

3.8. Parity and $L B W$. Ten studies were included in this category of meta-analysis [22, 24-26, 30, 34, 43, 45, 48, 50]. The final pooled meta-analysis showed no statistically significant difference in the rate of LBW among women who were primipara and multipara, $\mathrm{OR}=1.2(95 \% \mathrm{CI}=0.9,1.5)$ (Figure 7). 


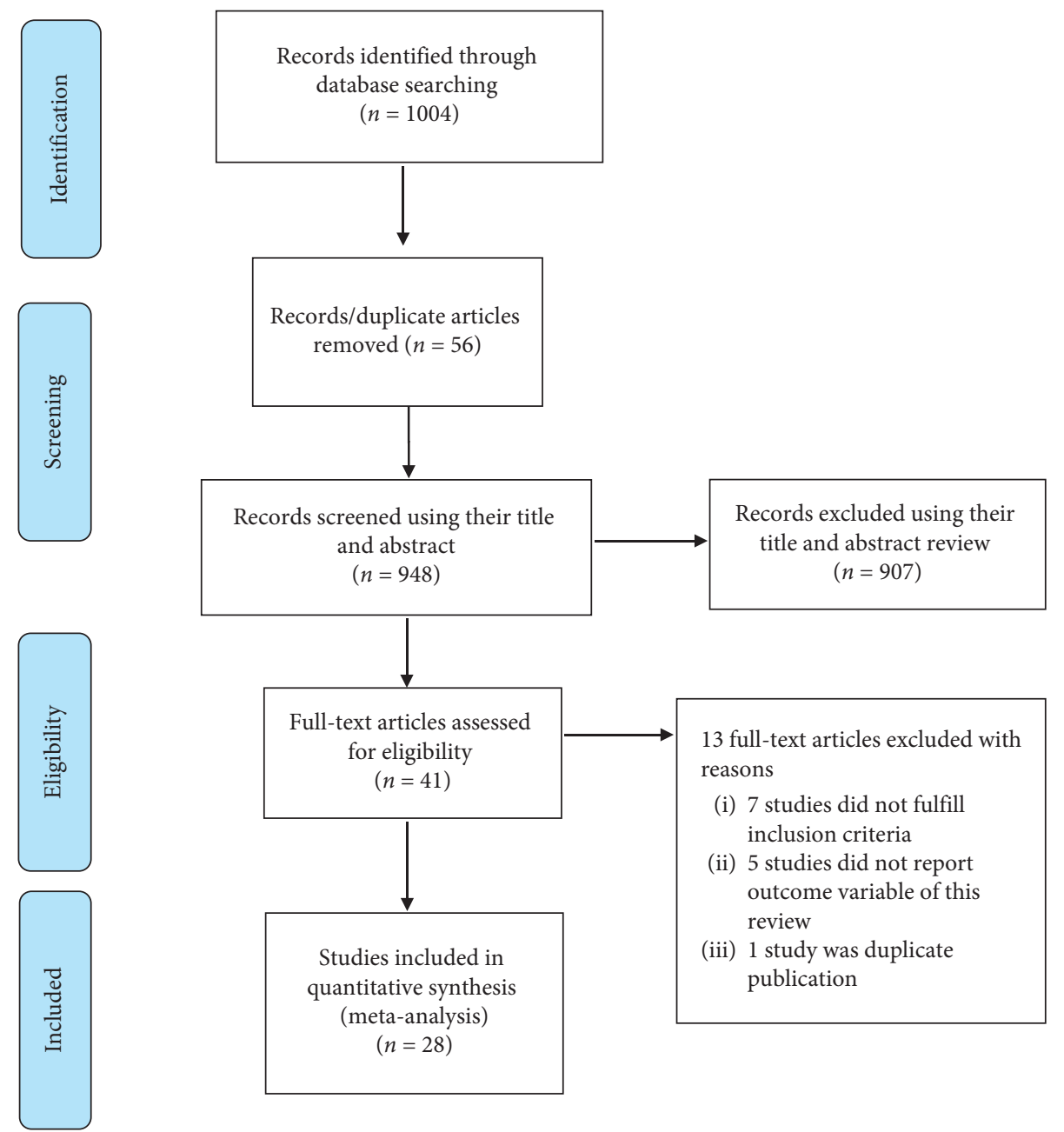

Figure 1: Flow diagram of the studies included in the meta-analysis.

3.9. Residence and $L B W$. From 13 studies included in this category of meta-analysis [22,24-26, 29, 34, 40, 43, 45-49], two studies showed higher LBW risk among babies born from urban resident mothers [34, 40]. But, nine studies showed an increased risk of LBW among rural residents [24-26, 29, 43, 46-49]. Two studies showed no statistically significant difference in the rate of LBW among rural and urban resident mothers $[22,45]$. The final pooled metaanalysis showed that babies born from rural mothers were at a higher risk of low birth weight compared to those born from an urban area, $\mathrm{OR}=1.75(95 \% \mathrm{CI}=1.19,2.56)$ (Figure 8).

3.10. Heterogeneity and Publication Bias. Egger's test was conducted to assess the publication bias of studies included in this meta-analysis. Accordingly, nonsignificant publication bias was observed in all categories of meta-analysis, $p$ value $>0.05$. For studies that present with high heterogeneity between studies, the random effect method of analysis was used.

3.11. Meta-Regression. The meta-analysis showed evidence of heterogeneity of included studies, and therefore, meta- regression was conducted to assess the source of heterogeneity. However, none of the covariates tested for source of heterogeneity were statistically significant. Therefore, the heterogeneity could be explained by other variables not included in this meta-analysis (Table 3 ).

\section{Discussion}

This systematic review and meta-analysis were carried out to assess the pooled prevalence of low birth weight and its determinant factors in Ethiopia. The weight of the newborn at birth is considered as the most important factor related to perinatal and infant morbidity and mortality [52, 53]. Low birth weight babies are almost 20 times more likely to die compared to normal birth weight babies [1].

This review found a higher prevalence of low birth weight in Ethiopia. The prevalence was 14.1\% (95\% $\mathrm{CI}=11.2,17.1$ ). This is almost similar to the prevalence of LBW in sub-Saharan Africa, which ranges from 13\% to $15 \%$ [1]. A study conducted in Cameroon showed a $13.5 \%$ prevalence of LBW [54]. A lower prevalence of LBW (8.7\%) was also observed in a study undertaken in Colombia [53]. While a higher prevalence $(30.3 \%)$ of LBW was found in a 
TABLE 1: Summary characteristics of studies included in the meta-analysis to show the prevalence of low birth weight in Ethiopia.

\begin{tabular}{|c|c|c|c|c|c|c|c|}
\hline $\begin{array}{l}\text { S. } \\
\text { No. }\end{array}$ & $\begin{array}{l}\text { Author, } \\
\text { publication year }\end{array}$ & Study design & $\begin{array}{l}\text { Year study } \\
\text { conducted }\end{array}$ & Sample size & Study area & $\begin{array}{l}\text { Mean birth } \\
\text { weight (in } \\
\text { grams) }\end{array}$ & $\begin{array}{c}\text { Prevalence of LBW (95\% } \\
\text { CI) }\end{array}$ \\
\hline 1 & $\begin{array}{l}\text { Zenebe et al, } \\
2014[46]\end{array}$ & $\begin{array}{c}\text { Institution- } \\
\text { based cross- } \\
\text { sectional }\end{array}$ & March-May, 2012. & 540 & $\begin{array}{l}\text { Gondar town, } \\
\text { Amhara } \\
\text { region }\end{array}$ & 2900 & $17.4(14.2,20.6)$ \\
\hline 2 & $\begin{array}{c}\text { Wado et al, } 2014 \\
\text { [43] }\end{array}$ & $\begin{array}{l}\text { Community- } \\
\text { based } \\
\text { prospective } \\
\text { cohort }\end{array}$ & $\begin{array}{c}\text { June } \\
\text { 2012-February } \\
2013\end{array}$ & 537 & Oromia region & 2989 & $17.9(14.66,21.14)$ \\
\hline 3 & $\begin{array}{l}\text { Teklehaimanot } \\
\text { et al, } 2014 \text { [39] }\end{array}$ & $\begin{array}{l}\text { Institution- } \\
\text { based cross- } \\
\text { sectional }\end{array}$ & $\begin{array}{l}\text { February-April, } \\
2013 .\end{array}$ & 253 & $\begin{array}{l}\text { Axum, Tigray } \\
\text { region }\end{array}$ & 3055 & $9.9(6.22,13.58)$ \\
\hline 4 & Tema, 2006 [40] & $\begin{array}{l}\text { Institution- } \\
\text { based cross- } \\
\text { sectional }\end{array}$ & $\begin{array}{c}\text { September } 1^{\text {st }} \text {, } \\
\text { 2002-March } 30^{\text {th }} \text {, } \\
2003\end{array}$ & 645 & $\begin{array}{c}\text { Jimma, } \\
\text { Oromia region }\end{array}$ & - & $22.5(19.28,25.72)$ \\
\hline 5 & $\begin{array}{l}\text { Gebremedhin } \\
\text { et al, } 2015 \text { [29] }\end{array}$ & $\begin{array}{l}\text { Institution- } \\
\text { based cross- } \\
\text { sectional }\end{array}$ & $\begin{array}{l}\text { Aug 2-Sep 12, } \\
2013\end{array}$ & 308 & Tigray region & 3094.9 & $14.6(10.66,18.54)$ \\
\hline 6 & $\begin{array}{c}\text { Zeleke et a, } 2012 \\
{[45]}\end{array}$ & $\begin{array}{c}\text { Institution- } \\
\text { based cross- } \\
\text { sectional }\end{array}$ & $\begin{array}{l}\text { May 1-July 30, } \\
2010 .\end{array}$ & 305 & $\begin{array}{l}\text { Gondar town, } \\
\text { Amhara } \\
\text { region }\end{array}$ & 2972 & $17.1(12.87,21.33)$ \\
\hline 7 & $\begin{array}{l}\text { Adane et al, } \\
2014[22]\end{array}$ & $\begin{array}{l}\text { Institution- } \\
\text { based cross- } \\
\text { sectional study }\end{array}$ & February 2013 & 481 & $\begin{array}{l}\text { Gondar } \\
\text { University } \\
\text { Hospital, } \\
\text { Amhara }\end{array}$ & 2977.7 & $11.2(8.38,14.02)$ \\
\hline 8 & $\begin{array}{l}\text { Demelash et al, } \\
2015 \text { [49] }\end{array}$ & $\begin{array}{l}\text { Case-control } \\
\text { study }\end{array}$ & $\begin{array}{l}\text { April 1st-August } \\
\text { 30th, } 2013\end{array}$ & 387 & $\begin{array}{l}\text { Bale Zone, } \\
\text { Oromia region }\end{array}$ & - & - \\
\hline 9 & $\begin{array}{l}\text { Assefa et al, } \\
2012[25]\end{array}$ & Cohort study & $\begin{array}{c}\text { December } \\
\text { 2009-November } \\
2010\end{array}$ & 956 & $\begin{array}{l}\text { Kersa, Oromia } \\
\text { region }\end{array}$ & - & $28.3(25.44,31.16)$ \\
\hline 10 & $\begin{array}{l}\text { Gebremedhin } \\
\text { et al, } 2012 \text { [29] }\end{array}$ & $\begin{array}{l}\text { Community- } \\
\text { based } \\
\text { prospective } \\
\text { cohort }\end{array}$ & $\begin{array}{l}\text { January-October } \\
2011\end{array}$ & 575 & $\begin{array}{l}\text { Sidama Zone, } \\
\text { SNNPR }\end{array}$ & 2896 & $16.5(13.47,19.53)$ \\
\hline 11 & $\begin{array}{c}\text { Desalegn, } 2015 \\
{[50]}\end{array}$ & $\begin{array}{l}\text { Case-control } \\
\text { study }\end{array}$ & $\begin{array}{l}\text { February to June } \\
2015\end{array}$ & $\begin{array}{c}\text { Case }=147, \\
\text { control }=294\end{array}$ & $\begin{array}{c}\text { Debre Berehan } \\
\text { Referral } \\
\text { hospital, } \\
\text { Amhara } \\
\text { region }\end{array}$ & $\begin{array}{l}\text { Case }=2077.55 \\
\text { control }=3230.0\end{array}$ & - \\
\hline 12 & $\begin{array}{c}\text { Teshome et al, } \\
2006[41]\end{array}$ & $\begin{array}{l}\text { Institution- } \\
\text { based } \\
\text { prospective } \\
\text { study }\end{array}$ & 2006 & 373 & $\begin{array}{l}\text { Gondor, } \\
\text { Amhara } \\
\text { region }\end{array}$ & 3003 & $15.4(11.74,19.06)$ \\
\hline 13 & $\begin{array}{c}\text { Madebo, } 1994 \\
\text { [33] }\end{array}$ & $\begin{array}{l}\text { Retrospective } \\
\text { study }\end{array}$ & 1989-1990 & 1,260 & $\begin{array}{l}\text { Sidama Zone, } \\
\text { SNNPR }\end{array}$ & 3,243 & $8(6.5,9.5)$ \\
\hline 14 & $\begin{array}{c}\text { Zerfu et al, } 2016 \\
\text { [47] }\end{array}$ & $\begin{array}{l}\text { Prospective } \\
\text { cohort study }\end{array}$ & - & 374 & $\begin{array}{l}\text { Arsi Zone, } \\
\text { Oromia region }\end{array}$ & - & $9.1(6.19,12.01)$ \\
\hline 15 & $\begin{array}{l}\text { Gebremariam, } \\
2005[28]\end{array}$ & $\begin{array}{l}\text { Cross- } \\
\text { sectional }\end{array}$ & 1999-2000 & 1441 & $\begin{array}{c}\text { Jimma } \\
\text { Hospital, } \\
\text { Oromia region }\end{array}$ & - & $10.02(8.47,11.57)$ \\
\hline 16 & $\begin{array}{c}\text { Nekatibeb and } \\
\text { Mariam, } 2007 \\
{[36]}\end{array}$ & $\begin{array}{l}\text { Cross- } \\
\text { sectional }\end{array}$ & 2005 & 1832 & $\begin{array}{l}\text { Metu Karl } \\
\text { Hospital, } \\
\text { Oromia } \\
\text { regions }\end{array}$ & 3147 & $8.6(7.32,9.88)$ \\
\hline 17 & $\begin{array}{c}\text { Feleke and } \\
\text { Enquoselassie, } \\
1999 \text { [27] }\end{array}$ & $\begin{array}{l}\text { Prospective } \\
\text { study }\end{array}$ & 1996-1997 & 4206 & Addis Ababa & 3065 & $9.1(8.23,9.97)$ \\
\hline
\end{tabular}


TABle 1: Continued.

\begin{tabular}{|c|c|c|c|c|c|c|c|}
\hline $\begin{array}{l}\text { S. } \\
\text { No. }\end{array}$ & $\begin{array}{c}\text { Author, } \\
\text { publication year }\end{array}$ & Study design & $\begin{array}{l}\text { Year study } \\
\text { conducted }\end{array}$ & Sample size & Study area & $\begin{array}{c}\text { Mean birth } \\
\text { weight (in } \\
\text { grams) }\end{array}$ & $\begin{array}{c}\text { Prevalence of LBW (95\% } \\
\text { CI) }\end{array}$ \\
\hline 18 & $\begin{array}{l}\text { Assefa et al, } \\
2004 \text { [25] }\end{array}$ & $\begin{array}{l}\text { Community- } \\
\text { based } \\
\text { longitudinal } \\
\text { study }\end{array}$ & 1992-1194 & 7,586 & $\begin{array}{l}\text { Jimma, } \\
\text { Illubaborand } \\
\text { Keffa, Oromia, } \\
\text { and SNNPR }\end{array}$ & 3066 & $10.0(9.33,10.67)$ \\
\hline 19 & $\begin{array}{c}\text { Enquoselassie } \\
\text { and } \\
\text { Minyilshewa, } \\
2000[26]\end{array}$ & $\begin{array}{l}\text { Retrospective } \\
\text { study }\end{array}$ & 1976-1996 & 9975 & $\begin{array}{c}\text { Tikure } \\
\text { Anbasa, Addis } \\
\text { Ababa }\end{array}$ & 3126 & $8.4(7.86,8.94)$ \\
\hline 20 & $\begin{array}{l}\text { Mengesha et al, } \\
2017 \text { [34] }\end{array}$ & $\begin{array}{l}\text { Cross- } \\
\text { sectional } \\
\text { survey }\end{array}$ & 2014 & 1152 & Tigray region & - & $10.5(8.73,12.27)$ \\
\hline 21 & $\begin{array}{c}\text { Abdo and Tesso, } \\
2016[21]\end{array}$ & $\begin{array}{l}\text { Facility-based } \\
\text { cross-sectional }\end{array}$ & 2015 & 327 & $\begin{array}{c}\text { Hosanna } \\
\text { town, SNNPR }\end{array}$ & - & $9.8(6.58,13.02)$ \\
\hline 22 & $\begin{array}{c}\text { Tigistu, } 2016 \\
\text { [42] }\end{array}$ & $\begin{array}{l}\text { Facility-based } \\
\text { cross-sectional }\end{array}$ & 2016 & 403 & $\begin{array}{l}\text { Dire Dawa } \\
\text { town }\end{array}$ & 3106 & $13.2(9.9,16.5)$ \\
\hline 23 & $\begin{array}{c}\text { Mihiretu } 2017 \\
\text { [35] }\end{array}$ & $\begin{array}{l}\text { Facility-based } \\
\text { cross-sectional } \\
\text { study }\end{array}$ & 2015 & 300 & $\begin{array}{c}\text { Wolaita Sodo } \\
\text { Referral } \\
\text { Hospital, } \\
\text { SNNPR }\end{array}$ & - & $6(3.31,8.69)$ \\
\hline 24 & $\begin{array}{l}\text { Aman Yesuf } \\
\text { et al, } 2016[48]\end{array}$ & $\begin{array}{l}\text { Case-control } \\
\text { study }\end{array}$ & 2013 & 453 & $\begin{array}{c}\text { Gondar and } \\
\text { Bahirdar } \\
\text { Referral } \\
\text { Hospital }\end{array}$ & - & - \\
\hline 25 & $\begin{array}{c}\text { Zerfu et al, } 2016 \\
{[47]}\end{array}$ & $\begin{array}{c}\text { In-depth } \\
\text { analysis EDHS }\end{array}$ & 2011 & 11,872 & $\begin{array}{l}\text { In-depth } \\
\text { analysis of } \\
\text { EDHS } 2011\end{array}$ & - & $29.1(28.28,29.92)$ \\
\hline 26 & $\begin{array}{c}\text { Kebede and } \\
\text { Larson, } 1994 \\
{[32]}\end{array}$ & $\begin{array}{l}\text { Retrospective } \\
\text { cohort }\end{array}$ & 1985-1988 & 2259 & $\begin{array}{l}\text { Jimma } \\
\text { Regional } \\
\text { Hospital, } \\
\text { Oromia }\end{array}$ & 2332 & $13.1(11.71,14.49)$ \\
\hline 27 & $\begin{array}{l}\text { Hadush et al, } \\
2017[31]\end{array}$ & $\begin{array}{l}\text { Facility-based } \\
\text { cross-sectional } \\
\text { study }\end{array}$ & 2017 & 422 & $\begin{array}{l}\text { Mekelle, } \\
\text { Tigray }\end{array}$ & 2807 & $27(22.76,31.24)$ \\
\hline 28 & $\begin{array}{c}\text { Sheferaw, } 1990 \\
{[38]}\end{array}$ & $\begin{array}{l}\text { Retrospective } \\
\text { cross-sectional }\end{array}$ & 1986-1988 & 1707 & $\begin{array}{l}\text { Jimma } \\
\text { hospital, } \\
\text { Oromia }\end{array}$ & 3183 & $12.3(10.74,13.86)$ \\
\hline
\end{tabular}

TABLE 2: Subgroup analysis of prevalence of low birth weight in Ethiopia.

\begin{tabular}{|c|c|c|c|c|}
\hline Subgroup & Number of studies included & Prevalence $(95 \% \mathrm{CI})$ & Test of heterogeneity $\left(I^{2}\right)$ & $p$ value \\
\hline \multicolumn{5}{|l|}{ By region } \\
\hline Addis Ababa city & 2 & $8.66(8.00,9.33)$ & $44.1 \%$ & 0.181 \\
\hline Amhara & 4 & $15.12(11.99,18.26)$ & $70.1 \%$ & 0.018 \\
\hline Dire Dawa city & 1 & $13.20(09.90,16.50)$ & - & - \\
\hline Oromia & 8 & $15.09(11.33,18.85)$ & $96.8 \%$ & $<0.001$ \\
\hline SNNPR & 4 & $09.99(06.02,13.96)$ & $90.1 \%$ & $<0.001$ \\
\hline Tigray & 4 & $15.36(08.57,22.15)$ & $94.3 \%$ & $<0.001$ \\
\hline Nation-based studies & 2 & $19.55(00.83,38.27)$ & $99.9 \%$ & $<0.001$ \\
\hline \multicolumn{5}{|l|}{ By study design } \\
\hline Cross-sectional study & 17 & $14.55(10.06,19.03)$ & $98.8 \%$ & $<0.001$ \\
\hline Cohort study & 8 & $13.03(10.62,15.45)$ & $97.0 \%$ & $<0.001$ \\
\hline \multicolumn{5}{|l|}{ By publication year } \\
\hline $1990-2000$ & 5 & $10.12(8.37,11.86)$ & $92.9 \%$ & $<0.001$ \\
\hline $2001-2010$ & 5 & $12.82(9.93,15.70)$ & $94.3 \%$ & $<0.001$ \\
\hline $2011-2017$ & 15 & $15.84(10.63,21.05)$ & $98.5 \%$ & $<0.001$ \\
\hline
\end{tabular}




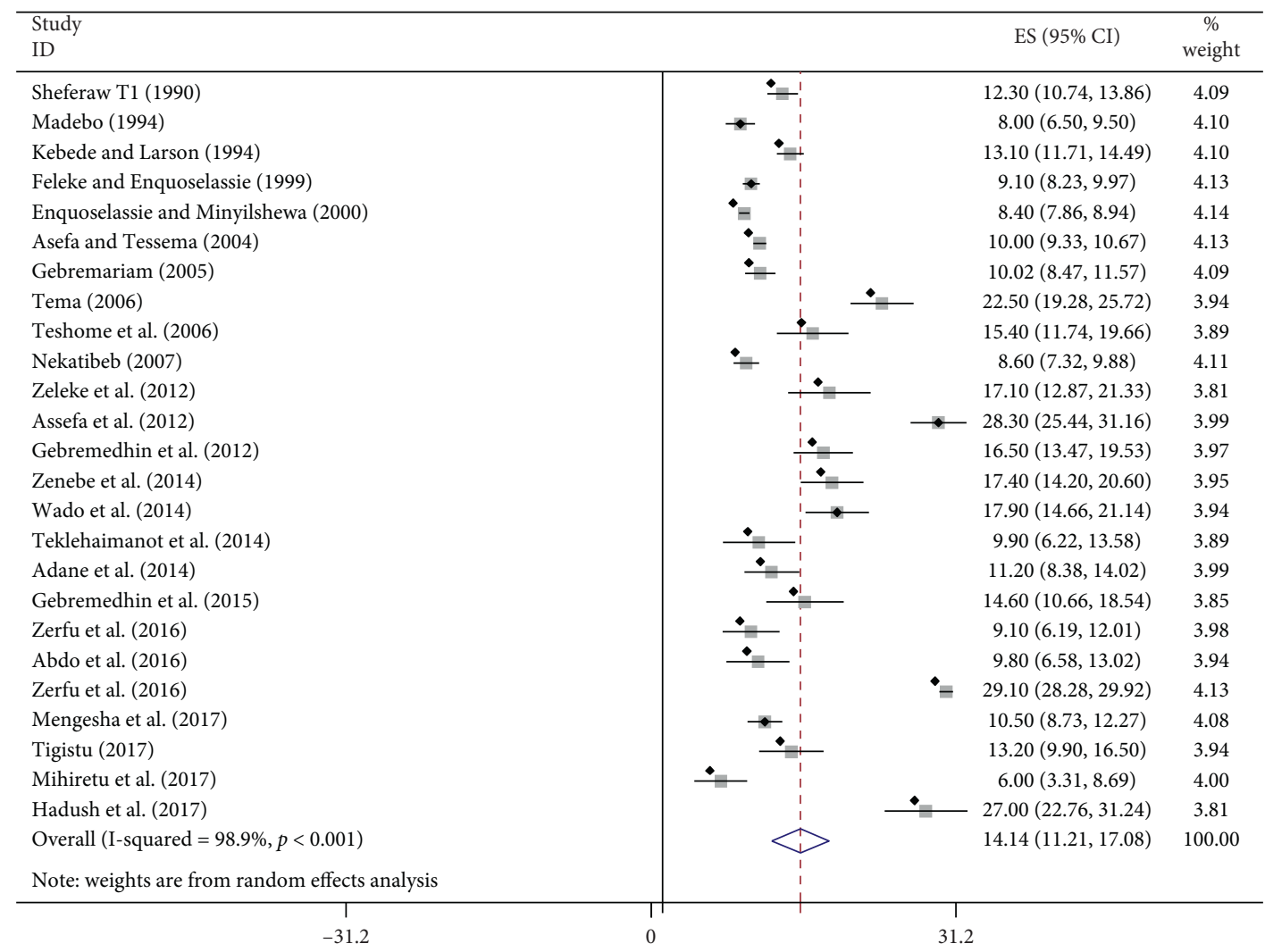

FIGURE 2: Forest plot displaying the pooled prevalence of low birth weight in Ethiopia.

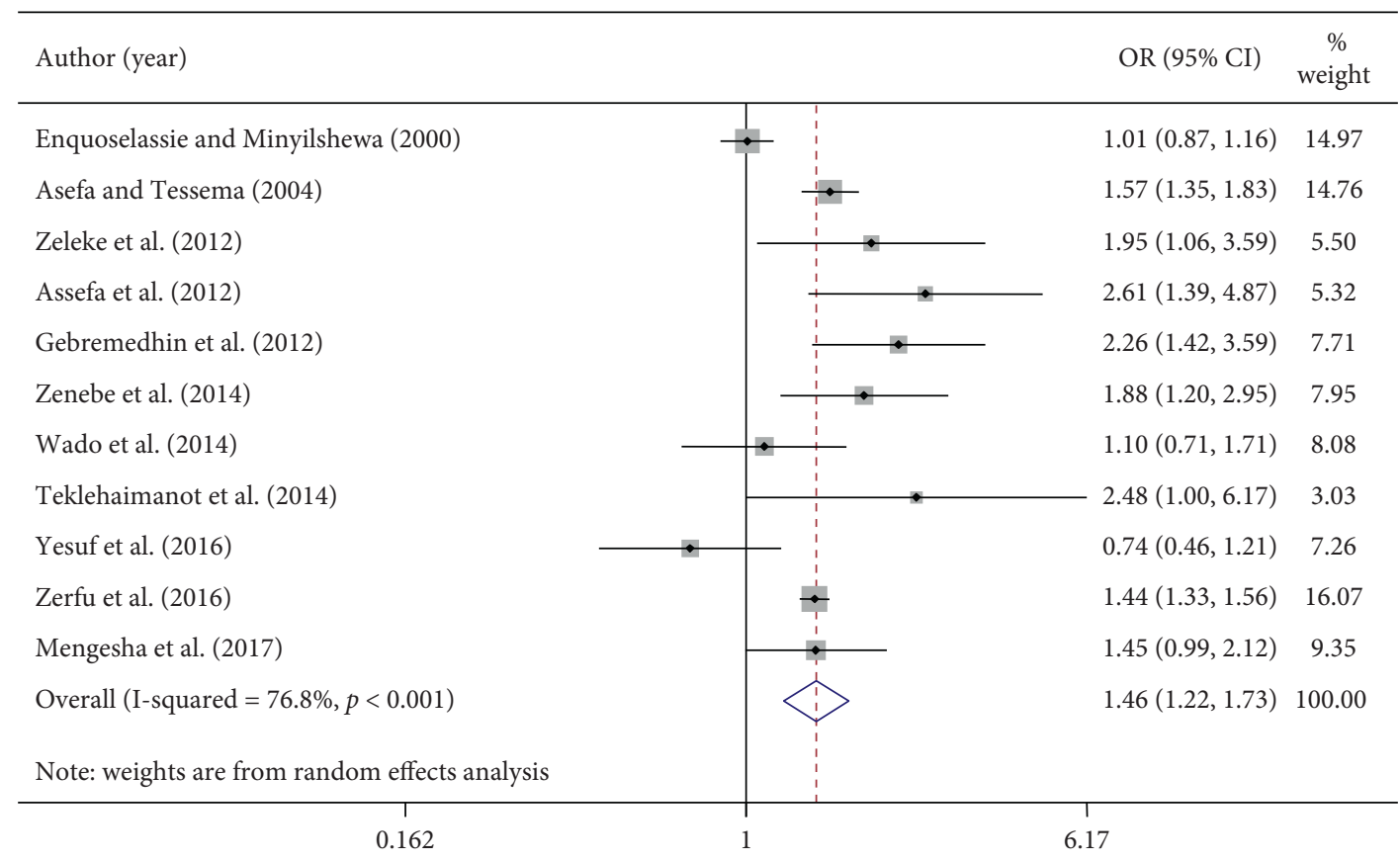

Figure 3: Forest plot displaying the association of sex of the newborn and low birth weight in Ethiopia.

study conducted in India [55]. The sociodemographic, economic, nutritional, and healthcare seeking behaviors of pregnant mothers and health service differences could be possible reasons for the higher and lower estimates.
A variety of differences in the prevalence of LBW between the different regions in Ethiopia was found. A higher prevalence of LBW (15.4\%) was seen in Tigray region, while the lowest (8.66\%) was in Addis Ababa, Capital city of 


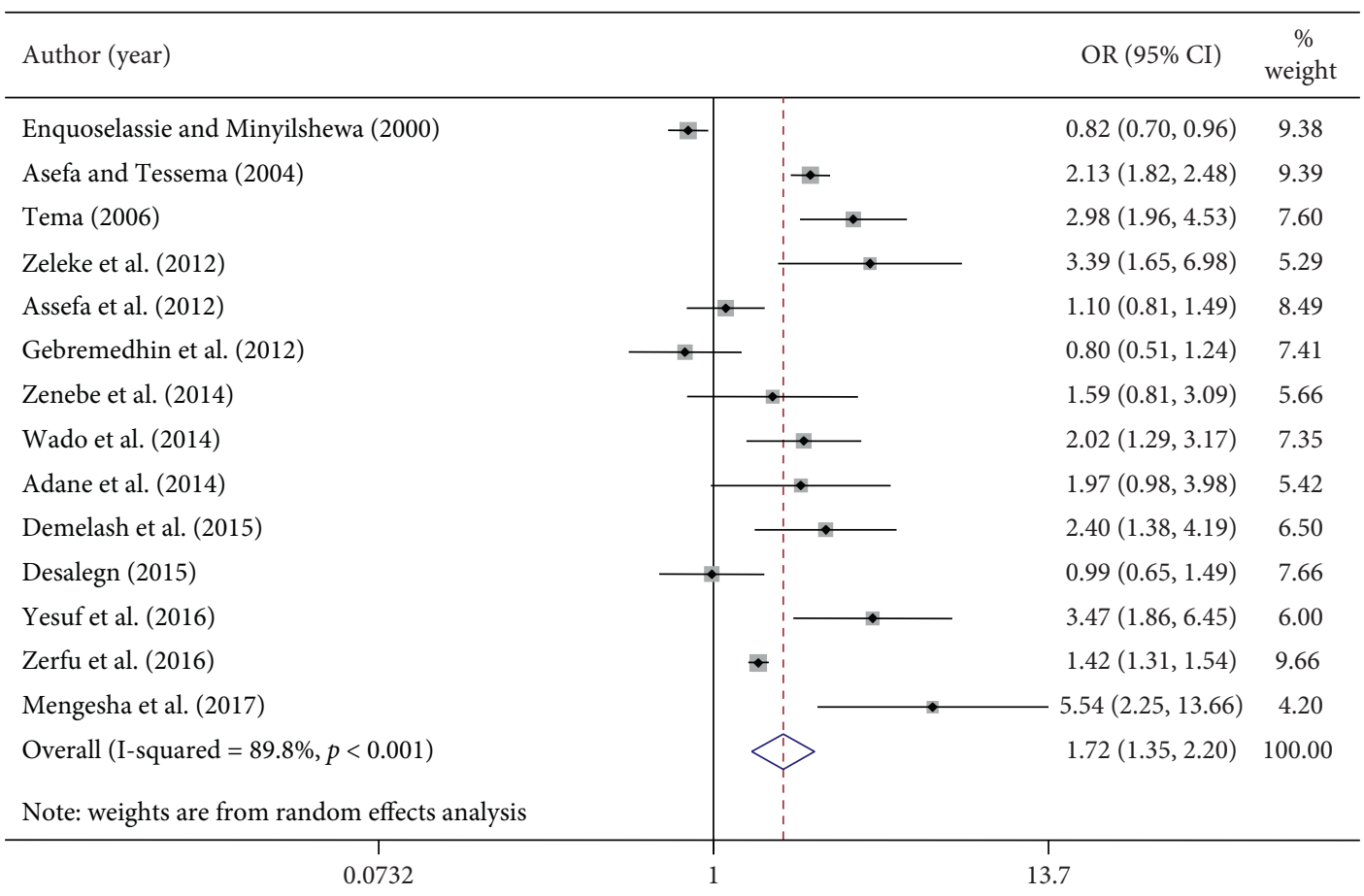

FIGURE 4: Forest plot displaying the association of absence of prenatal care and low birth weight of the newborn in Ethiopia.

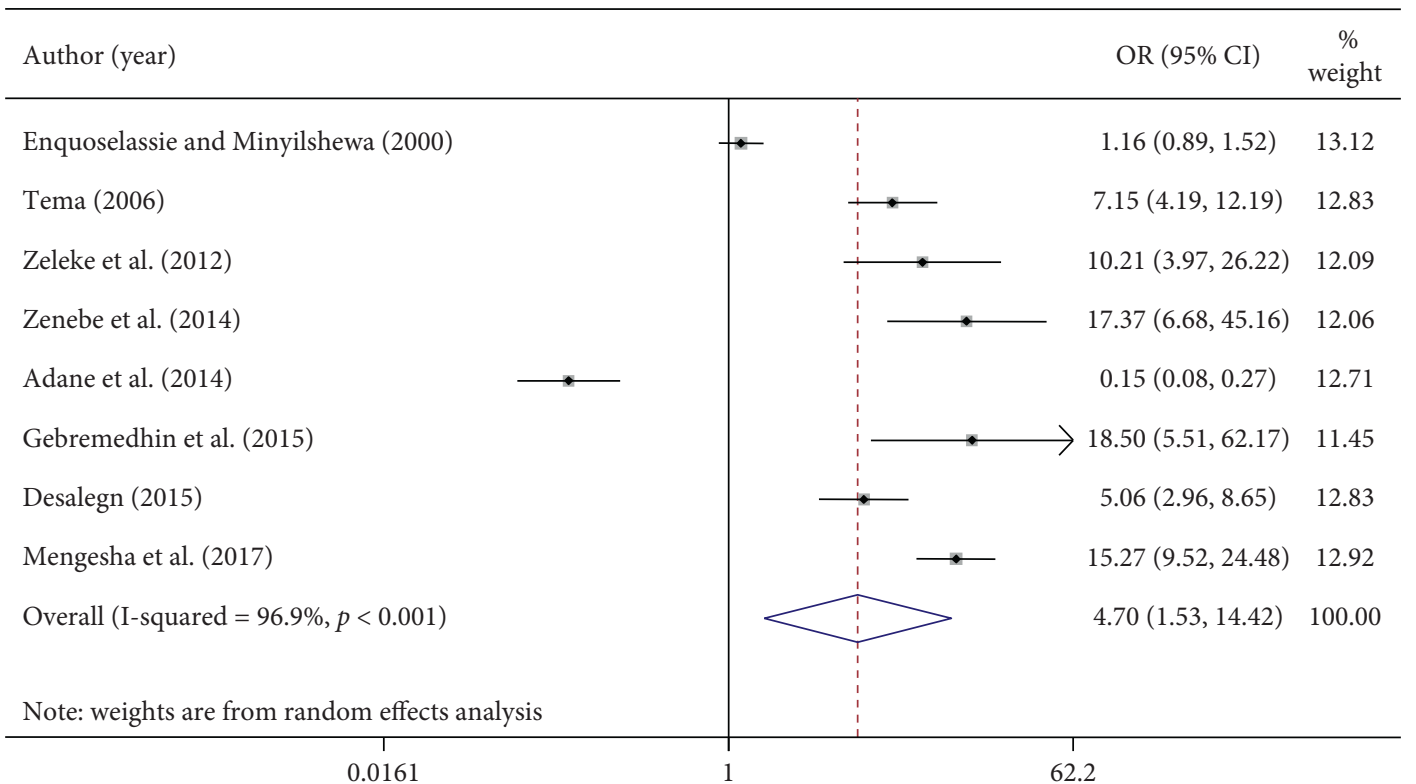

Figure 5: Forest plot displaying the association of preterm delivery before 37 weeks of gestation and low birth weight Ethiopia.

Ethiopia. Such disparities could be due to the difference in the sociodemographic, economic, healthcare seeking behavior, and nutritional status of pregnant women in different regions of the country. The subgroup analysis of the prevalence of LBW by publication year showed an increasing trend from 1990 to 2017. The rising prevalence in the LBW could be attributed to the increasing health care seeking behavior and reduced home delivery, which all increased the case detection rate over time in Ethiopia.

The finding of this meta-analysis also showed the presence of a statistically significant association between the sex of the newborn and low birth weight, OR $1.5(1.2,1.7)$. Female newborn babies had a $46 \%$ higher odd of being low birth weight than male babies. This finding was congruent with the study conducted in Arunachal Pradesh [56]. The higher LBW risk among females than male newborn babies 


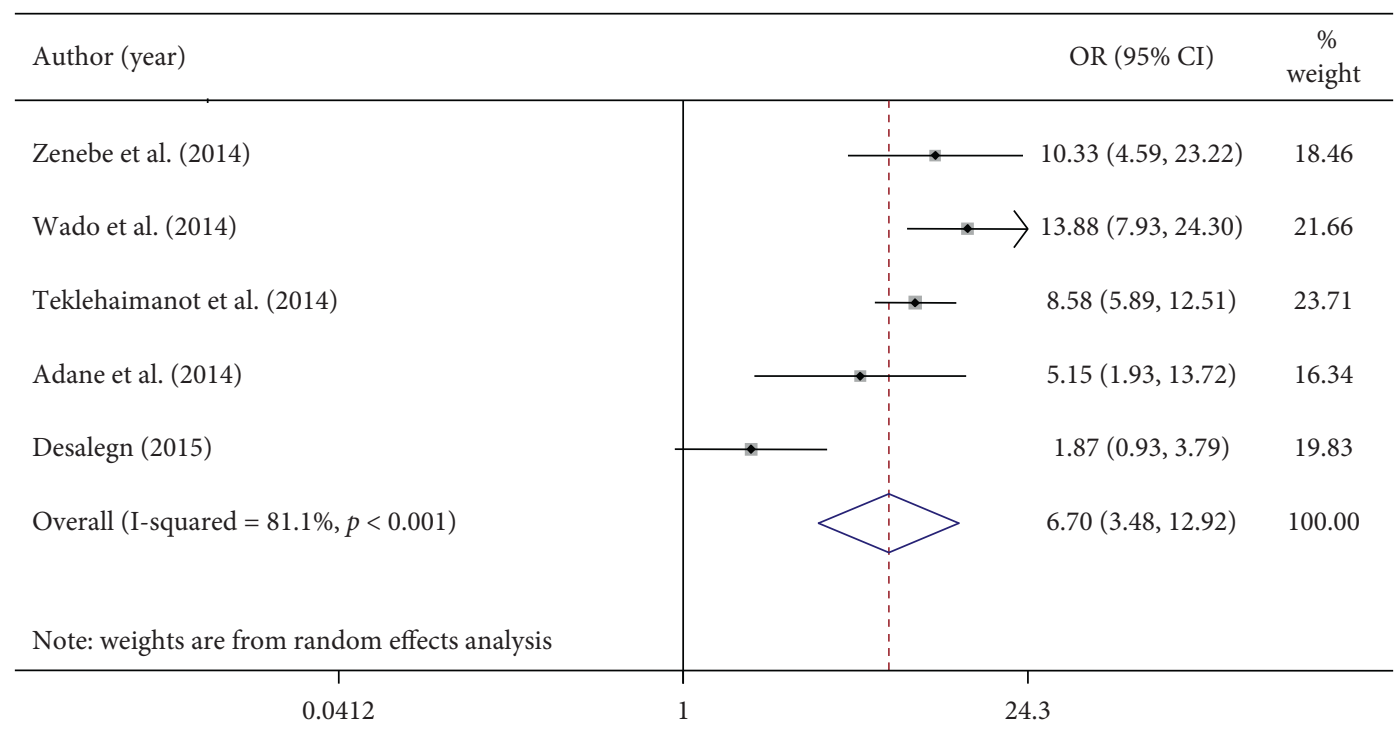

FIGURE 6: Forest plot displaying the association of pregnancy-induced hypertension on low birth weight in Ethiopia.

\begin{tabular}{|c|c|c|c|}
\hline Author (year) & & OR $(95 \% \mathrm{CI})$ & $\begin{array}{c}\% \\
\text { weight }\end{array}$ \\
\hline Enquoselassie and Minyilshewa (2000) & 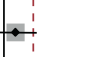 & $1.08(0.93,1.26)$ & 14.91 \\
\hline Asefa and Tessema (2004) & & $1.43(1.21,1.69)$ & 14.67 \\
\hline Zeleke et al. (2012) & & $5.30(2.48,11.32)$ & 5.72 \\
\hline Assefa et al. (2012) & $\rightarrow$ & $1.19(0.77,1.82)$ & 10.18 \\
\hline Gebremedhin et al. (2012) & & $2.16(1.27,3.67)$ & 8.50 \\
\hline Wado et al. (2014) & & $0.87(0.46,1.66)$ & 7.03 \\
\hline Adane et al. (2014) & & $1.21(0.68,2.13)$ & 7.97 \\
\hline Desalegn (2015) & & $1.14(0.76,1.71)$ & 10.55 \\
\hline Yesuf et al. (2016) & & $0.64(0.40,1.03)$ & 9.38 \\
\hline Mengesha et al. (2017) & & $0.86(0.59,1.25)$ & 11.08 \\
\hline Overall $(\mathrm{I}$-squared $=75.1 \%, p<0.001)$ & & $1.23(0.98,1.54)$ & 100.00 \\
\hline Note: weights are from random effects analysis & & & \\
\hline 0.0883 & \multicolumn{3}{|c|}{11.3} \\
\hline
\end{tabular}

FiguRE 7: Forest plot displaying the association of being primipara and low birth weight in Ethiopia.

could be due to the difference in chromosomal factors among male and female babies. Term male infants weigh between 150 and $200 \mathrm{~g}$ more than females [16].

Mothers who did not attend ANC for that pregnancy were 1.7 (OR 1.4, 2.2) times more likely to have low birth weight. Studies conducted in other countries also support this idea $[16,57-60]$. Mothers who attended ANC are likely to get health education and counseling about pregnancy, which enables them to avoid modifiable risk factors for low birth weight. For example; studies have shown that prenatal interventions such as prevention of smoking during pregnancy, nutritional education, and prevention and early treatment of medical conditions during pregnancy are responsible for the reduction of low birth weight babies among women who follow antenatal care [60]. However, the effectiveness of prenatal care in reducing pregnancy complications depends on the number of visits and the time the women booked for prenatal care. Therefore, studies showing the effect of frequency of antenatal follow-ups and the birth of the baby are needed.

In this meta-analysis, preterm babies were 4.7 (OR 1.5, 14.5) times more likely to be low birth weight compared to term babies. A baby born early has less time in the mother's uterus to grow and gain weight, and much of a fetus's weight is increased during the latter part of the mother's pregnancy [16]. 


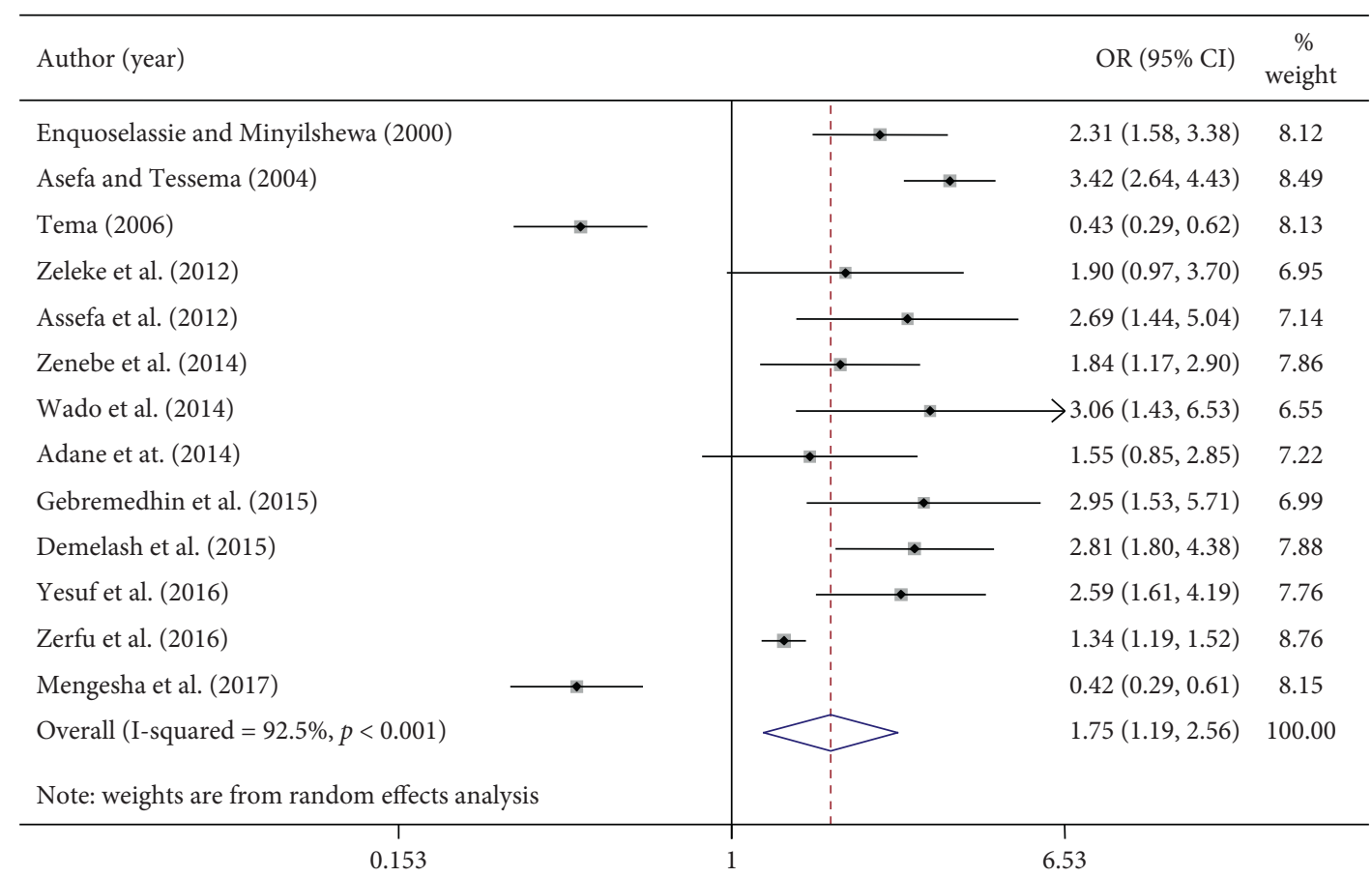

FIGURE 8: Forest plot displaying the association of rural residence and low birth weight in Ethiopia.

TABLE 3: Meta-regression analysis of the different study-level covariates explaining possible sources of heterogeneity.

\begin{tabular}{lcc}
\hline Study characteristics & Coefficient & $p$ value \\
\hline Publication year & 0.227 & 0.162 \\
Sample size & $<0.001$ & 0.578 \\
Cohort study design & -1.219 & 0.671 \\
Addis Ababa city & -4.45 & 0.595 \\
Amhara & 2.042 & 0.791 \\
Oromia & 1.938 & 0.790 \\
SNNPR & -3.157 & 0.681 \\
Tigray & 2.158 & 0.779 \\
National study & 6.344 & 0.451 \\
\hline
\end{tabular}

Mothers who had pregnancy-induced hypertension were 6.7 times more likely to have low birth weight babies, OR 6.7 (3.5, 12.9). This finding is in line with the studies conducted in Karnataka, India, and Campinas, Brazil [61, 62]. This might be due to the trophoblast invasion into the spiral arteries that supply the placenta is incomplete due to pregnancy-induced hypertension. The reduced uteroplacental blood perfusion leads to intrauterine growth retardation and low birth weight [63].

Parity is not associated with low birth weight in this metaanalysis. This could be because the studies included in this analysis have only two categories for parity (primipara and multipara). Previous studies showed that first and four and above births are more likely to be low birth weight compared to second and third births. The reason for this is that the uterus, especially the vascular structures, is not well matured for all purposes during the first pregnancy. The uterine vascular conditions start to decline increasing the risk of low birth weight beginning with the fourth pregnancy [16].

Maternal place of residence was associated with low birth weight (OR $1.6(1.2-2.6))$. Mothers living in rural areas had a $75 \%$ higher risk of giving low birth weight babies than mothers living in the urban areas. This finding is consistent with the study conducted in Punjab [64]. Rural resident pregnant women are more prone to maternal psychosocial stress, which is implicated in increasing the release of catecholamine and cortisol, and subsequently stimulates the release of corticotrophinreleasing hormone $(\mathrm{CRH})$ through cortisol. The release of $\mathrm{CRH}$ has been hypothesized to initiate the onset of labor via a series of biochemical processes, while cortisol has been linked with intrauterine growth restriction and low birth weight [65].

Although this study has assessed the effect of selected variables on the occurrence of low birth weight, the factors are not limited to these. Previous studies have also reported additional factors associated with low birth weight. These include poverty, nonuse of antenatal care, low social support and unwanted pregnancy [43], preterm birth, maternal chronic illness and maternal weight below $50 \mathrm{~kg}$ [29], and a history of perinatal death and 
antepartum hemorrhage [22]. Therefore, future review and meta-analysis studies should consider addressing other factors not included in the current study.

This review used a comprehensive search strategy to retrieve both published and unpublished studies. Several authors were involved in each step of the meta-analysis. The review followed the PRISMA guideline for metaanalysis. On the other hand, because of the nature of the studies included, parity was dichotomized only into two, which may lead to a lack of association with low birth weight. Therefore, further studies are recommended to identify the effect of parity on low birth weight in Ethiopia. This study included the effect of selected factors on low birth weight. The factors are not limited to those included in this review, and further reviews to show the association of LBW with other sociodemographic, maternal, and newborn characteristics are needed.

\section{Conclusions}

The prevalence of low birth weight was high in Ethiopia, with high variation across the different regions in the country. This requires targeted interventions to regions with a higher prevalence of LBW. This review also showed the association of LBW with several factors. Variables such as sex of the newborn, prenatal care follow-up, pregnancy-induced hypertension, preterm delivery, and residence of the mother were significantly associated with LBW. No statistically significant association was observed in the rate of LBW among primigravida and multigravida mothers. Emphasis should be given to mothers living in rural areas. Community-based health promotion activities on maternal nutrition during pregnancy, antenatal follow-up, prevention, and early treatment of PIH are needed to reduce the high burden of LBW in Ethiopia.

\section{Abbreviations}

$\begin{array}{ll}\text { ANC: } & \text { Antenatal care } \\ \text { LBW: } & \text { Low birth weight } \\ \text { OR: } & \text { Odds ratio } \\ \text { PIH: } & \text { Pregnancy-induced hypertension } \\ \text { SNNPR: } & \text { Southern Nations, Nationalities and Peoples' } \\ & \text { Region of Ethiopia } \\ \text { WHO: } & \text { World Health Organization. }\end{array}$

\section{Data Availability}

The data used to support this study are included within this article.

\section{Conflicts of Interest}

The authors declare that they have no conflicts of interest

\section{Authors' Contributions}

NAK was involved in the design, selection of articles, study quality assessment, data extraction, statistical analysis, and writing the first draft of the manuscript. GMK, GAF, AAM, and AKB were also involved in the article selection, statistical analysis, and writing and editing of the manuscript. All authors approved the final version of the manuscript.

\section{Acknowledgments}

The authors would like to acknowledge all authors of the studies included in this review.

\section{Supplementary Materials}

Additional file 1. Table: quality assessment based on the JBI critical appraisal tool checklists of included case-control study with their authors and scores. Additional file 2. Table: quality assessment based on the JBI critical appraisal tool checklists of included cohort studies with their authors and scores. Additional file 3. Table: quality assessment based on the JBI critical appraisal tool checklists of included analytical cross-sectional studies with their authors and scores. (Supplementary Materials)

\section{References}

[1] T. M. Wardlaw, Low Birthweight: Country, Regional and Global Estimates, UNICEF, New York, NY, USA, 2004.

[2] World Health Organization, WHA Global Nutrition Targets 2025: Low Birth Weight Policy Brief, World Health Organization, Geneva, Switzerland, 2012.

[3] N. S. Paneth, "The problem of low birth weight," The Future of Children, vol. 5, no. 1, pp. 19-34, 1995.

[4] M. S. Kramer, The Epidemiology of Low Birthweight. Maternal and Child Nutrition: The First 1,000 Days, Karger Publishers, Berlin, Germany, 2013.

[5] UNICEF, "Undernourishment in the womb can lead to diminished potential and predispose infants to early death. UNICEF data: monitoring the situation of children and women," 2013, http://www.w3.org/data unicef org/nutrition/ low-birthweight\# sthash BG4IvrwC dpuf.

[6] World Health Organization, Care of the Preterm and/or LowBirth-Weight Newborn, World Health Organization, Geneva, Switzerland, 2015.

[7] R. E. Black, L. H. Allen, Z. A. Bhutta et al., "Maternal and child undernutrition: global and regional exposures and health consequences," The Lancet, vol. 371, no. 9608, pp. 243-260, 2008.

[8] C. A. Mathers and M. B. Gomes, "Low birth weight: causes and consequences," Diabetology \& Metabolic Syndrome, vol. 5, no. 1, p. 49, 2013.

[9] K.N. B. Ikenna, S. N. Uwaezuoke, J. C. Chinawa et al., "Maternal risk factors associated with low birth weight neonates: a multi-centre, cross-sectional study in a developing country," Journal of Neonatal Biology, vol. 4, no. 3, 2015.

[10] O. M. Muchemi, E. Echoka, and A. Makokha, "Factors associated with low birth weight among neonates born at Olkalou District Hospital, Central Region, Kenya," Pan African Medical Journal, vol. 20, no. 1, 2015.

[11] J. Siza, "Risk factors associated with low birth weight of neonates among pregnant women attending a referral hospital in northern Tanzania," Tanzania Journal of Health Research, vol. 10, no. 1, pp. 1-8, 2008.

[12] R. K. Bhaskar, K. K. Deo, U. Neupane et al., “A case control study on risk factors associated with low birth weight babies in 
Eastern Nepal," International Journal of Pediatrics, vol. 2015, p. 7, Article ID 807373, 2015.

[13] K. Rajashree, H. Prashanth, and R. Revathy, "Study on the factors associated with low birth weight among newborns delivered in a tertiary-care hospital, Shimoga, Karnataka," International Journal of Medical Science and Public Health, vol. 4, no. 9, pp. 1287-1290, 2015.

[14] N. Khan and M. Jamal, "Maternal risk factors associated with low birth weight," Journal of the College of Physicians and Surgeons--Pakistan: JCPSP, vol. 13, no. 1, pp. 25-28, 2003.

[15] G. M. Monawar Hosain, N. Chatterjee, A. Begum, and S. C. Saha, "Factors associated with low birthweight in rural Bangladesh," Journal of Tropical Pediatrics, vol. 52, no. 2, pp. 87-91, 2005.

[16] J. V. de Bernabé, T. Soriano, R. Albaladejo et al., "Risk factors for low birth weight: a review," European Journal of Obstetrics \& Gynecology and Reproductive Biology, vol. 116, no. 1, pp. 3-15, 2004.

[17] H. Joshi, P. Srivastava, A. Agnihotri, M. Joshi, S. Chandra, and V. Mahajan, "Risk factors for low birth weight (lbw) babies and its medico-legal significance," Journal of Indian Academy of Forensic Medicine, vol. 32, no. 3, 2010.

[18] V. Domple, M. Doibale, A. Nair, and P. Rajput, "Assessment of maternal risk factors associated with low birth weight neonates at a tertiary hospital, Nanded, Maharashtra," Nigerian Medical Journal, vol. 57, no. 1, p. 37, 2016.

[19] T. Nonpanitaya, "Risk factors associated with delivering low birth weight infants in term pregnant women in pathum thani hospital," Journal of Health Science, vol. 17, no. V, pp. 1363-1376.

[20] R. A. Mahumud, M. Sultana, and A. R. Sarker, "Distribution and determinants of low birth weight in developing countries," Journal of Preventive Medicine and Public Health, vol. 50, no. 1, pp. 18-28, 2017.

[21] R. A. E. T. Abdo and F. Y. Tesso, "Prevalence and associated factors of adverse birth outcomes among women attended maternity ward at negest elene mohammed memorial general hospital in hosanna town, SNNPR. Ethiopia," Journal Women's Health Care, vol. 5, no. 324, 2016.

[22] A. A. Adane, T. A. Ayele, L. G. Ararsa, B. D. Bitew, and B. M. Zeleke, "Adverse birth outcomes among deliveries at gondar university hospital, northwest Ethiopia," BMC Pregnancy and Childbirth, vol. 14, no. 1, p. 90, 2014.

[23] T. Alemu and M. Umeta, "Prevalence and predictors of "small size" babies in Ethiopia: in-depth analysis of the Ethiopian demographic and health survey, 2011," Ethiopian Journal of Health Sciences, vol. 26, no. 3, pp. 243-250, 2016.

[24] M. Asefa and F. Tessema, "Patterns of birth weight at a community level in southwest Ethiopia," Ethiopian Journal of Health Sciences, vol. 14, no. 1, 2004.

[25] N. Assefa, Y. Berhane, and A. Worku, "Wealth status, mid upper arm circumference (MUAC) and antenatal care (ANC) are determinants for low birth weight in Kersa, Ethiopia," PloS One, vol. 7, no. 6, Article ID e39957, 2012.

[26] F. Enquoselassie and A. Minyilshewa, "Changes in birthweight of hospital-delivered neonates in addis ababa," Ethiopian Journal of Health Development, vol. 14, no. 2, pp. 169-176, 2000.

[27] Y. Feleke and F. Enquoselassie, "Maternal age, parity and gestational age on the size of the newborn in Addis Ababa," East African Medical Journal, vol. 76, no. 8, pp. 468-471, 1999.

[28] A. Gebremariam, "Factors predisposing to low birth weight in Jimma hospital south western Ethiopia," East African Medical J0ournal, vol. 82, no. 11, p. 554, 2005.
[29] M. Gebremedhin, F. Ambaw, E. Admassu, and H. Berhane, "Maternal associated factors of low birth weight: a hospital based cross-sectional mixed study in Tigray, northern Ethiopia," BMC Pregnancy and Child birth, vol. 15, no. 1, p. 222, 2015.

[30] S. Gebremedhin, F. Enquselassie, and M. Umeta, "Independent and joint effects of prenatal zinc and vitamin a deficiencies on birthweight in rural Sidama, southern Ethiopia: prospective cohort study," PloS One, vol. 7, no. 12, Article ID e50213, 2012.

[31] M. Y. Hadush, A. H. Berhe, and A. A. Medhanyie, "Foot length, chest and head circumference measurements in detection of low birth weight neonates in Mekelle, Ethiopia: a hospital based cross sectional study," BMC Pediatrics, vol. 17, no. 1 , p. 111, 2017.

[32] A. Kebede and C. Larson, "The health consequences of intrauterine growth retardation in southwestern Ethiopia," Tropical Doctor, vol. 24, no. 2, pp. 64-69, 1994.

[33] T. Madebo, "A two year retrospective study of birth weight in Sidamo regional hospital," Ethiopian Medical Journal, vol. 32, no. 4, pp. 255-260, 1994.

[34] H. G. Mengesha, A. D. Wuneh, B. Weldearegawi, and D. L. Selvakumar, "Low birth weight and macrosomia in Tigray, Northern Ethiopia: who are the mothers at risk?" BMC Pediatrics, vol. 17, no. 1, p. 144, 2017.

[35] A. E. T. Mihiretu, "Negash T perinatal death and associated factors in wolaita sodo referral hospital, southern Ethiopia: a facility based cross-sectional study," Prim Health Care, vol. 7, p. 269.

[36] G. G. Nekatibeb and A. Mariam, "Analysis of birth weight in metu karl hospital: south west Ethiopia," Ethiopian Medical Journal, vol. 45, no. 2, pp. 195-202, 2007.

[37] E. Mariam, M. Abera, M. Tesfaye, and N. Fentahun, "Maternal and fetal outcome of pregnancy related hypertension in Mettu Karl referral hospital, Ethiopia," Journal of Ovarian Research, vol. 8, no. 1, p. 10, 2015.

[38] T. Sheferaw, "Some factors associated with birth weight in Jima, southwestern Ethiopia," Ethiopian Medical Journal, vol. 28, no. 4, pp. 183-190, 1990.

[39] N. Teklehaimanot, T. Hailu, and H. Assefa, "Prevalence and factors associated with low birth weight in axum and laelay maichew districts, north Ethiopia: a comparative cross sectional study," International Journal of Nutrition and Food Sciences, vol. 3, no. 6, pp. 560-566, 2014.

[40] T. Tema, "Prevalence and determinants of low birth weight in Jimma zone, southwest Ethiopia," East African Medical Journal, vol. 83, no. 7, p. 366, 2006.

[41] D. Teshome, T. Telahun, D. Solomon, and I. Abdulhamid, “A study on birth weight in a teaching-referral hospital, Gondar, Ethiopia," The Central African Journal of Medicine, vol. 52, no. 1-2, pp. 8-11, 2006.

[42] Y. Tigistu, Low Birth Weight and Associated Factors in Public Health Facilities in Diredawa Town, Ethiopia, Harmaya University, Dire Dawa, Ethiopia, 2016.

[43] Y. D. Wado, M. F. Afework, and M. J. Hindin, "Effects of maternal pregnancy intention, depressive symptoms and social support on risk of low birth weight: a prospective study from southwestern Ethiopia," PloS One, vol. 9, no. 5, Article ID e96304, 2014.

[44] M. Wagnew, M. Dessalegn, A. Worku, and J. Nyagero, "Trends of preeclampsia/eclampsia and maternal and neonatal outcomes among women delivering in addis ababa selected government hospitals, Ethiopia: a retrospective cross- 
sectional study," The Pan African Medical Journal, vol. 25, no. 2, 2016.

[45] B. M. Zeleke, M. Zelalem, and N. Mohammed, "Incidence and correlates of low birth weight at a referral hospital in Northwest Ethiopia," The Pan African Medical Journal, vol. 12, no. 1, p. 4, 2012.

[46] K. Zenebe, T. Awoke, and N. Birhan, "Low birth weight \& associated factors among newborns in gondar town, North West Ethiopia: institutional based cross-sectional study," Indo Global Journal of Pharmaceutical Sciences, vol. 4, no. 2, pp. 74-80, 2014.

[47] T. A. Zerfu, M. Umeta, and K. Baye, "Dietary diversity during pregnancy is associated with reduced risk of maternal anemia, preterm delivery, and low birth weight in a prospective cohort study in rural Ethiopia," The American Journal of Clinical Nutrition, vol. 103, no. 6, pp. 1482-1488, 2016.

[48] F. E. Aman Yesuf, S. Hagos, and M. Assefa, "Effect of interpregnancy interval on low birth weight in gondar and Bahir dar referral hospital: a case control study from north west Ethiopia," Journal of Health, Medicine and Nursing, vol. 31, 2016.

[49] H. Demelash, A. Motbainor, D. Nigatu, K. Gashaw, and A. Melese, "Risk factors for low birth weight in Bale zone hospitals, South-East Ethiopia: a case-control study," BMC Pregnancy and Childbirth, vol. 15, no. 1, p. 264, 2015.

[50] L. Desalegn, "BMC research notes," Determinants of Low Birth Weight in Debre Berehan Referral Hospital, North Shoa Zone, Amhara Regional State, Ethiopia (a Case - Control Study), vol. 11447 pages, 2015.

[51] "Addis Ababa university institutional repository," December 2016, http://etd.aau.edu.et/handle/123456789/1557.

[52] C. Rodriguez, E. Regidor, and J. L. Gutierrez-Fisac, "Low birth weight in Spain associated with sociodemographic factors," Journal of Epidemiology \& Community Health, vol. 49, no. 1, pp. 38-42, 1995.

[53] A. M. Pinzon-Rondon, V. Gutierrez-Pinzon, H. MadrinanNavia, J. Amin, P. Aguilera-Otalvaro, and A. Hoyos-Martinez, "Low birth weight and prenatal care in Colombia: a crosssectional study," BMC Pregnancy and Childbirth, vol. 15, p. 118, 2015.

[54] T. Njim, J. Atashili, R. Mbu, and S. P. Choukem, "Low birth weight in a sub-urban area of Cameroon: an analysis of the clinical cut-off, incidence, predictors and complications," BMC Pregnancy and Childbirth, vol. 15, p. 288, 2015.

[55] J. S. Deshmukh, D. D. Motghare, S. P. Zodpey, and S. K. Wadhva, "Low birth weight and associated maternal factors in an urban area," Indian Pediatrics, vol. 35, no. 1, pp. 33-36, 1998.

[56] B. Mondal, "Low birth weight in relation to sex of baby, maternal age and parity: a hospital based study on tangsa tribe from Arunachal Pradesh," Journal of the Indian Medical Association, vol. 96, no. 12, pp. 362-364, 1998.

[57] H. Barros, M. Tavares, and T. Rodrigues, "Role of prenatal care in preterm birth and low birthweight in Portugal," Journal of Public Health, vol. 18, no. 3, pp. 321-328, 1996.

[58] T. Joyce, "Impact of augmented prenatal care on birth outcomes of medicaid recipients in New York city," Journal of Health Economics, vol. 18, no. 1, pp. 31-67, 1999.

[59] P. L. Birthweight, Committee to Study the Prevention of Low Birthweight, Division of Health Promotion and Disease Prevention, National Academy Press, Washington, DC, USA, 1985.
[60] G. R. Alexander and C. C. Korenbrot, "The role of prenatal care in preventing low birth weight," The Future of Children, vol. 5, no. 1, pp. 103-120, 1995.

[61] C. S. Metgud, V. A. Naik, and M. D. Mallapur, "Factors affecting birth weight of a newborn-a community based study in rural Karnataka, India," PloS One, vol. 7, no. 7, Article ID e40040, 2012.

[62] P. R. Coutinho, J. G. Cecatti, F. G. Surita, J. P. d. Souza, and S. S. d. Morais, "Factors associated with low birth weight in a historical series of deliveries in Campinas, Brazil," Revista da Associação Médica Brasileira, vol. 55, no. 6, pp. 692-699, 2009.

[63] L. A. Rahman, N. N. Hairi, and N. Salleh, "Association between pregnancy induced hypertension and low birth weight; a population based case-control study," Asia Pacific Journal of Public Health, vol. 20, no. 2, pp. 152-158, 2008.

[64] A. Jalil, A. Usman, and R. Zakar, "Maternal factors determining low birth weight in Punjab: a secondary data analysis," FWU Journal of Social Sciences, vol. 10, no. 2, p. 70, 2016.

[65] G. A. Kayode, M. Amoakoh-Coleman, I. A. Agyepong, E. Ansah, D. E. Grobbee, and K. Klipstein-Grobusch, "Contextual risk factors for low birth weight: a multilevel analysis," PloS One, vol. 9, no. 10, Article ID e109333, 2014. 